\title{
Maximizing Utilization of Some Organic Fertilizers to Produce The Highest Yield of Cowpea
}

\author{
Riham M. Faiyad, Ahmed G. Bador and Rasha E. El-Mahdy \\ Soil Fertility and Plant Nutrition Department, Soil, Water and Environment Institute. \\ Giza,Egypt
}

\begin{abstract}
$\mathbf{T}$ WO FIELD experiments were established in middle Nile Delta alluvial soils. The study was conducted on the two successive summer seasons of 2016 and 2017 in the experimental farm of Tag El-Ezz Agricultural Research Station, Agricultural Research Center (ARC), Dakahlia Governorate, Egypt. The experiment was laid out in a split plot design with three replications, assigning nine treatments to study the effect of three forms of organic fertilization (without, farmyard manure and compost rice straw) as main plot, and 3 forms of foliar application (control, mix of micro nutrients (Fe, $\mathrm{Zn}$ and $\mathrm{Mn}$ ) and humic acid (HA)) as sub plot on growth, yield and chemical constituents of cowpea (Vigna unguiculata L.). The obtained results showed that, addition of organic amendments in forms of compost rice straw significantly increased plant growth parameters (plant height, fresh weight, dry weight and number of leaves), chemical composition of leaves (chlorophyll a, b and total chlorophyll content, N, P, K, Fe, Zn and Mn as well as quality parameters (C. protein, T. carbohydrates, C. fiber, ash and total sugar of cowpea seeds except with moisture conetnt) and yield as well as its components (No. of pods/plant, No. of seed/pod, 100 seed weight and seed yield, also availability of soil (N, P and K). On the other hand; mix of micro elements gave significant positive effect and higher average values for all parameters previously. The interaction effect between organic fertilization and foliar application show a primitive effect on all parameters and the highest mean values of parameters was recorded with using CRS as organic fertilization and mix of micro nutrients as foliar application.
\end{abstract}

Key words: FYM, Rice straw, Micro nutrients, Humic acid and Cowpea plant.

\section{Introduction}

Cowpea (Vigna unguiculata L.) commonly known as "Lobia" is a pulse, fodder and green manure crop, in Egypt it is a remarkable plant nutrition. The cowpea seeds are a huge nutritional values, which contains the vitamins and proteins for human and increased the national economy. The little leaves and pods are eaten as vegetables, and also it is feed for animals. Belong to family leguminous, which fixed the nitrogen from the air and increment it in soil, this role is very important for this plants especially when the soil suffer from a lack of nitrogen (Dugie et al., 2009). In 2011, the cultivated area of cowpea in Egypt was about 8381 fed, yielding about 1.088 Mg (FAO, 2006).

Manures represent a serious pollution problem resulting from the huge accumulation of such material. These animal wastes are known to be heavily contaminated with pathogenic bacteria and parasites causing a direct health risk (Hanajima et al. 2006) .Egypt are a highly successful producer of rice with average yield of more than $6.5 \mathrm{tha}^{1}$ in $2011 / 2012$. Harvesting index of Egyptian rice varieties left up to $60 \%$ straw (FAO Rice Market Monitor 2013). Therefore, the most common practices for recycling rice straw and most of organic manure are composting (Ghosh, 2004). Since composting are of the most promising low-cost technologies to convert agro-industrial contaminant solid wastes into value-added bio fertilizer (Misra et al., 2003). Farmyard manure (FYM) and compost of rice straw (CRS) are the most important and widely used bulky organic manures. Farmyard manures have been used as a soil conditioner since ancient times and there 
benefit have not been fully harnessed because of large quantities required in order to satisfy the nutritional needs to crops (Pennington et al., 2015). Rice straw is poor in nitrogen and rich in carbon, which decreases the composting process. With increasing the basal nitrogen content of rice straw by adding different organic raw materials contains farmyard manure and chicken manure, can be decreased the high $\mathrm{C} / \mathrm{N}$ ratio (Hellal, 2007). Organic fertilizers generally maintain soil chemical, physical, biological properties beside preserving the moisture holding capacity of soil and resulting in increasing crop productivity along with maintaining the quality of crops. Although the organic manures includes plant nutrients in small quantities and presence of growth promoting principles like hormones and enzymes, besides plant nutrients make them essential for improvement of soil fertility and productivity.

With increasing agricultural production has increased using of humic acid and the most economical humic acid is almost applied to the soil directly and/or as a foliar application to the plants. Potassium humate is a good source of humic acid. Its stimulation to plant growth is a provenance of nutrients supply to the plant. Nardi et al. (1999) noticed that the biological activity of the humic acid was attributed to their chemical structure and their functional groups, which could interact with harmonic-binding proteins in the membrane system, evoking a hormonelike response. Deficiencies of micronutrients are more frequent in many soil types; especially with increase soil $\mathrm{pH}$ over 7.5 the availability and uptake of micronutrients by plants decrease (Eisa and Ali, 2014). Micronutrients have considerable significant effects, as limiting factors, on the productivity of legumes. Microelements as iron play a serious role in synthesis of chlorophyll and chloroplast formation. $\mathrm{Fe}$, Mo and $\mathrm{B}$ as nitrogenase play a vital role of enzymes activity, peroxidase and catalase (Marschner, 1998).

The study was established to evaluate effect of foliar application of mixture of $\mathrm{Fe}, \mathrm{Zn}$ and $\mathrm{Mn}$ as well as humic acid in form of potassium hamate on cowpea plants under organic fertilization in forms of farmyard manure and compost of rice straw.

\section{Material And Methods}

A filed study was established to evaluate effect of foliar application of microelements as well as humic acid on cowpea plants under organic fertilization conditions on growth, yield and chemical constituents under surface irrigated alluvial soil conditions.

\section{Experimental Site}

Tow field experiments were established in middle Nile delta alluvial soils. The study was conducted on the two successive summer seasons of 2016 and 2017 in the experimental farm of Tag El-Ezz Agricultural research station, Agricultural research center (ARC), Dakahlia governorate, Egypt. Random disturbed soil samples from surface of the soil $(0-30 \mathrm{~cm})$ were collected before planting during the tow growing seasons. Soil physical, chemical, and nutritional properties of the experimental site were determined according to Page et al. (1982) and Klute (1986) these data were presented in Table 1.

\section{Experiment Description}

The experimental design was split plot design with three replications to study the effect of foliar application of microelements ( $\mathrm{Fe}, \mathrm{Zn}$ and $\mathrm{Mn}$ ) as well as humic acid (HA) (as potassium humate, $\mathrm{HK} ; 10 \% \mathrm{~K}_{2} \mathrm{O}$ and $85 \% \mathrm{HA}$ ) on cowpea plants growth, yield and chemical constituents under soil application of two types of organic fertilizers as farmyard manure (FYM) and compost of rice straw (CRS). The experiment was arranged, assigning nine treatments consisting of three forms of organic amendments (without, FYM and CRS) as main plot, and 3 forms of foliar application (control, mixture of (Fe, $\mathrm{Zn}$ and $\mathrm{Mn}$ ) and $\mathrm{HK}$ ) as sub plots. Thus, the total numbers of the experimental plot were 27 plots. The experimental units included 6 ridges, $60 \mathrm{~cm}$ in width, $5 \mathrm{~m}$ in length, the middle three ridges were possessed for yield determinations, whereas the other three rows were used to measure plant growth characters. Seeds of cowpea were sown in hills at $15 \mathrm{~cm}$ apart on one side of the ridges ( 2 seeds/hill) on the mid of April during two seasons 2016 and 2017, respectively. The fertilizers of NPK were applied at rate of $45 \mathrm{~kg} \mathrm{~N} \mathrm{fed}^{-1}$ as ammonium sulfate $(20.5 \% \mathrm{~N}), 22.5 \mathrm{~kg} \mathrm{P}_{2} \mathrm{O} \mathrm{fed}^{-1}$ as super phosphate $\left(15.5 \% \mathrm{P}_{2} \mathrm{O}_{5}\right)$ and $24 \mathrm{~kg} \mathrm{~K}_{2} \mathrm{O}$ fed ${ }^{-1}$ as potassium sulfate $\left(48 \% \mathrm{~K}_{2} \mathrm{O}\right)$. Phosphorus fertilizer was added to the soil during land preparation, while $\mathrm{N}$ and $\mathrm{K}$ fertilizers were applied in two equal doses; after one month and at flowering stage. Organic fertilizers were incorporated to the soil surface during land preparation at the rate of $10 \mathrm{~m}^{3} \mathrm{fed}^{-}$ ${ }^{1}$ for each FYM and CRS. Chemical analyses of the organic amendments used were presented in Table 2. 
TABLE 1. Physical, chemical, and nutritional properties of the experimental field during years 2016 and 2017 before planting

\begin{tabular}{|c|c|c|}
\hline \multirow{2}{*}{ Soil Characteristics } & \multicolumn{2}{|c|}{ Growing season } \\
\hline & 2016 & 2017 \\
\hline \multicolumn{3}{|l|}{ I. Physical properties } \\
\hline \multicolumn{3}{|l|}{ Particle size distribution } \\
\hline Coarse sand & 3.45 & 3.84 \\
\hline Fine sand & 28.93 & 27.31 \\
\hline Silt & 38.81 & 39.45 \\
\hline Clay & 28.81 & 29.40 \\
\hline Soil Texture Class & Sand clay loam & Sand clay loam \\
\hline \multicolumn{3}{|l|}{ II. Chemical properties } \\
\hline $\mathrm{pH}, 1: 2.5$ soil suspension & 8.08 & 7.93 \\
\hline EC, soil past, $\mathrm{dS} \mathrm{m}^{-1}$ & 5.92 & 5.81 \\
\hline \multicolumn{3}{|l|}{ Soluble cations, $\mathrm{meq} / 100 \mathrm{~g}$ soil } \\
\hline $\mathrm{Ca}^{2+}$ & 1.75 & 1.67 \\
\hline $\mathrm{Mg}^{2+}$ & 1.17 & 1.08 \\
\hline $\mathrm{Na}^{+}$ & 2.88 & 2.71 \\
\hline $\mathrm{K}^{+}$ & 0.40 & 0.35 \\
\hline \multicolumn{3}{|l|}{ Soluble anions, $\mathrm{meq} / 100 \mathrm{~g}$ soil } \\
\hline $\mathrm{CO}_{3}^{2-}$ & - & - \\
\hline $\mathrm{HCO}_{3}^{-}$ & 1.92 & 1.79 \\
\hline $\mathrm{Cl}^{-}$ & 2.60 & 2.59 \\
\hline $\mathrm{SO}_{4}^{2-}$ & 1.68 & 1.56 \\
\hline $\mathrm{CaCO}_{3}, \%$ & 3.98 & 4.03 \\
\hline S.P \% & 60.1 & 58.9 \\
\hline $\mathrm{OM}, \%$ & 1.23 & 1.32 \\
\hline \multicolumn{3}{|l|}{ III. Nutritional properties } \\
\hline $\mathrm{KCl}$ extractable $\mathrm{N}, \mathrm{mg} \mathrm{kg}^{-1}$ & 50.9 & 61.2 \\
\hline $\mathrm{NaHCO}_{3}$ Extractable P, mg kg-1 & 4.49 & 4.13 \\
\hline Ammonium Acetate Extractable $\mathrm{K}, \mathrm{mg} \mathrm{kg}^{-1}$ & 143.2 & 145.4 \\
\hline
\end{tabular}

TABLE 2. Average chemical analysis of the organic fertilizers used during two growing seasons

\begin{tabular}{lcc}
\hline \multicolumn{1}{c}{ Organic fertilizer properties } & FYM & CRS \\
\hline pH 1:5 & 6.71 & 6.18 \\
EC 1:10 $\left(\mathrm{dSm}^{-1}\right)$ & 4.12 & 3.68 \\
Organic matter (\%) & 32.72 & 35.13 \\
Organic carbon (\%) & 19.10 & 20.51 \\
Total nitrogen (\%) & 1.27 & 1.51 \\
C/N ratio & 15.04 & 13.58 \\
Total Phosphorus (\%) & 0.47 & 0.53 \\
Total Potassium (\%) & 0.69 & 0.93 \\
\hline FYM= farmyard manure CRS= compost of rice straw & &
\end{tabular}

$\overline{\mathrm{FYM}}=$ farmyard manure, $\mathrm{CRS}=$ compost of rice straw. 
Microelements foliar application were consists of mix of 300, 150 and 100 ppm for iron, zinc and manganese, as EDTA chelated form respectively, whereas $\mathrm{HK}$ was applied at rate of $2 \mathrm{~g} \mathrm{l}^{-1}$ and sprayed three times starting from beginning of flowering stage, with 15 days intervals. During the two growing seasons plant growth parameters were measured, whereas at harvesting time yield and its components, chemical constituents and quality of cowpea seeds were determined as follows:

a. Vegetative parameters

A random sample of 4 plants from each plot was taken at 60 days after planting. All vegetative growth parameters i.e., plant length $(\mathrm{cm})$, number of leaves plant ${ }^{-1}$, fresh weight of leaves plant ${ }^{-1}$ (g) and dry weights of leaves plant-1 (g) were determined. Chlorophyll content in fresh leaves was estimated according to method described by Gavrilenko and Zigalova (2003).

\section{b. Yield and its components}

At harvesting time (90 days after planting), No. of pods plant ${ }^{-1}$, No. of seed pod ${ }^{-1}, 100$ seed weight (g) and seed yield $\mathrm{kg} \mathrm{fed}^{-1}$ were determined.

\section{c. Chemical constituents and seed quality}

Samples of leaves and seeds were oven dried at $70{ }^{\circ} \mathrm{C}$ then fine grinded and wet digested using wet-digestion using concentrated sulfuric acid and hydrogen peroxide $\left(\mathrm{H}_{2} \mathrm{O}_{2}\right)$ according to FAO method (FAO, 1980). Macro-elements (N, P and K) and microelements (Fe, $\mathrm{Zn}$ and $\mathrm{Mn}$ ) were determined in leaves and seeds (Westerman, 1990) as well as, macronutrients content as \% and microelements as $\mu \mathrm{g} \mathrm{g}^{-1}$. Total carbohydrates, \% (Shumaila and Safdar, 2009), fiber, ash, moisture and total sugar were described according to (AOAC, 2000). Protein content (\%) was calculated by multiplying $\mathrm{N}$ percentage $\mathrm{x} 6.25$ (FAO, 2003). According to the technique of analysis variance (ANOVA) and the least significant difference (L.S.D) method data were statistically analyzed and compared the deference between the means of treatment values to the methods described by Gomez and Gomez, (1984). All statistical analyses were performed using analysis of variance technique by means of CoSTATE Computer Software.

\section{Results And Discution}

\section{Vegetative growth parameters}

Average data presented in Table 3 revealed the effect of organic fertilization (without, FYM and CRS), foliar application (control, mix of (Fe, $\mathrm{Zn}, \mathrm{Mn}$ ) and $\mathrm{HK}$ ) and their interaction on average values of vegetative growth parameters as (plant height $(\mathrm{PH})$, fresh weight $(\mathrm{FW})$, dry weight (DW) and number of leaves (NPL)) during the two successive growing seasons of 2016- 2017. Concerning the effect of organic fertilization on cowpea plants, data presented a significant effect and the highest values were recorded at the application of CRS which were $(75.88,260.70$, 36.44 and 25.67) respectively compared to the control. The notability in the vegetative growth by addition of organic fertilizer might be referring to its convenient effect on the physical properties of the soil or due to the slow release of nutrients Ozores Hampton et al. (2011). Moreover, organic manure guaranty higher levels of comparatively obtainable nutritional elements, especially $\mathrm{N}$, which is basically, desired for plant growth Amanullah et al. (2007). Many studies have attempted to estimate the prominence of organic manures in vegetables product. Senjobi et al. (2010) found that the employ of organic manures increased all the growth characters of the green vegetable. Different studies have found advantageous effects of organic fertilization on soil characters expressed as magnitude intensity, water-holding capability and other soil physical properties (Fawole et al., 2010). The acquired results are in pretty endorsement with El-Gizawy et al. (2013), Mahmoud et al. (2013), Bandani et al. (2014) and Shafeek et al. (2017).

In the same table, plant height, fresh weight, dry weight and number of leaves increased significantly by using foliar application (mix of (Fe, Zn, Mn)and HK) comparing with untreated plants (control). The highest mean values of plant growth parameters indicated with mix of elements (Fe, $\mathrm{Zn}, \mathrm{Mn}$ ) which were 78.11, 265.99, 37.07 and 26.56 respectively. Usually, micronutrientdeficiency problems are found in soils. Thus, it is greater to be sprayed cations on the leaves, as foliar application supplies nutrients for plants faster compared with fertilizer application to soil. In addition, it might related to the effect of microelements in plant physiology; iron which plays an important role in sundry vital processes in plant such as photosynthesis consequently affecting plant growth; zinc is important for ${ }^{14} \mathrm{C}$ fixed in the primary photosynthetic process (Lincoln and Zeiger, 2002). Zn raised photosynthetic efficiency, which was reflected as simulative effect on vegetative growth plant and also zinc is a component of a variety of enzymes such as proteinase, dehydrogenase, phosphohydrases and peptidase (metabolism of carbohydrates, phosphate and protein) and zinc

Egypt. J. Soil. Sci. 59, No. 1 (2019) 
is known to stimulate plant resistance to dry and hot weather (El-Tohamy and El-Greadly, 2007), also zinc directly involved in biosynthesis of IAA hormone which stimulate cell division and cell elongation; Manganese is involved in the evolution of Oxygen in photosynthesis (Hill reaction). It is a component of a lot of enzyme systems. It has also function in chloroplast as a part of electron transport system and electron-transfer (oxidation-reduction) reactions (Srivastava and Gupta, 1996). Similar results in many crops were reported by Salih (2013) and Balai et al. (2017).

On the other hand, the effect of interaction between organic fertilizers and foliar application on plant growth parameters, data in Fig. 1 indicated that using of the treatments under investigation significantly increased parameters of growth, the highest mean values were optioned with using CRS and microelements.

\section{Chemical composition in leaves}

\section{Chlorophyll content}

Data in Table 4 showed main effects of organic fertilization (without, FYM and CRS), foliar application of (control, mix of $(\mathrm{Fe}+\mathrm{Zn}+\mathrm{Mn})$ and $\mathrm{HK}$ ) and their interaction on average values of chlorophyll a, b and total during growing seasons of 2016 and 2017. Statistical analyses of data in Table 4 revealed that addition of organic amendments significantly increased chlorophyll $\mathrm{a}, \mathrm{b}$ and total chlorophyll content of leaves. The maximum chlorophyll content was observed in plants treated with CRS. They were $0.777,0.546$ and $0.662 \mathrm{mg} / \mathrm{g} \mathrm{FW}$ respectively comparing with untreated plants. CRS contains essential nutrient elements associated with high photosynthetic activities. Similar results were established by El -Gizawy et al. (2013), Mahmoud et al. (2013) and Shafeek et al. (2017).

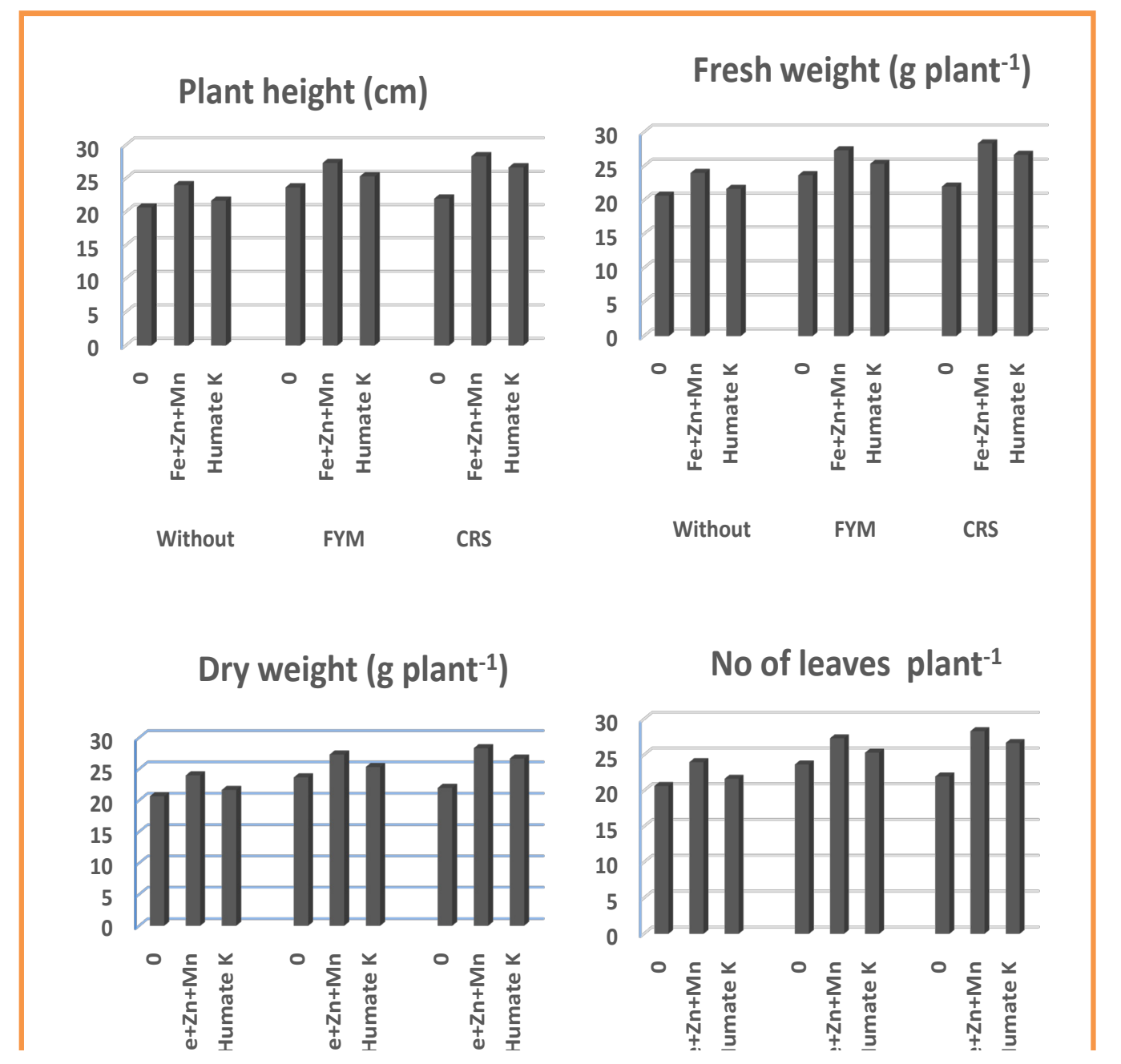

Fig. 1. Average values of plant growth parameters as affected with interaction of organic fertilization and foliar application during twogrowing seasons of 2016 and 2017 
TABLE 3. Average values of plant growth parameters as affected with individual adding of organic fertilization and foliar application during two growing seasons of 2016 and 2017

\begin{tabular}{|c|c|c|c|c|}
\hline Treatments & PH(cm) & FW $\left(\right.$ gplant $\left.^{-1}\right)$ & DW $\left(\right.$ gplant $\left.^{-1}\right)$ & NPL \\
\hline \multicolumn{5}{|c|}{ Organic fertilization } \\
\hline Without & 69.42 & 244.44 & 34.47 & 22.11 \\
\hline FYM & 73.42 & 256.74 & 35.79 & 25.44 \\
\hline CRS & 75.88 & 260.70 & 36.44 & 25.67 \\
\hline $\operatorname{LSD}_{\text {at } 5 \%}$ & 1.24 & 4.14 & 0.46 & 0.85 \\
\hline \multicolumn{5}{|c|}{ Foliar application } \\
\hline 0 & 66.52 & 238.67 & 33.57 & 22.11 \\
\hline $\operatorname{Micro}(\mathrm{Fe}+\mathrm{Zn}+\mathrm{Mn})$ & 78.11 & 265.99 & 37.07 & 26.56 \\
\hline Humic acid (humate K) & 74.09 & 257.23 & 36.07 & 24.56 \\
\hline $\mathrm{LSD}_{\text {at } 5 \%}$ & 0.62 & 3.32 & 0.81 & 0.70 \\
\hline
\end{tabular}

$\overline{\mathrm{PH}}=$ plant height, $\mathrm{FW}=$ fresh weight, $\mathrm{DW}=$ dry weight, $\mathrm{NPL}=$ No. of leaves plant ${ }^{-1}$.

TABLE 4. Average values of chlorophyll a, b and total in leaves (mg/g FW) as affected with organic fertilization and foliar application as well as their interaction during two growing seasons of 2016 and 2017

\begin{tabular}{|c|c|c|c|c|}
\hline & Treatments & Chl. amgg $^{-1}$ FW & $\begin{array}{c}\text { Chl. b } \text { mgg }^{-1} \\
\text { FW }\end{array}$ & $\begin{array}{c}\text { Total Chl.mgg-1 } \\
\text { FW }\end{array}$ \\
\hline \multicolumn{5}{|c|}{ Organic fertilization } \\
\hline & Without & 0.744 & 0.519 & 0.631 \\
\hline & FYM & 0.764 & 0.537 & 0.650 \\
\hline & CRS & 0.777 & 0.546 & 0.662 \\
\hline \multirow{2}{*}{\multicolumn{2}{|c|}{$\mathrm{LSD}_{\text {at } 5 \%}$}} & 0.005 & 0.001 & 0.003 \\
\hline & & Foliar application & & \\
\hline & 0 & 0.730 & 0.507 & 0.619 \\
\hline & $\operatorname{Micro}(\mathrm{Fe}+\mathrm{Zn}+\mathrm{Mn})$ & 0.787 & 0.555 & 0.671 \\
\hline & Humic acid (humate K) & 0.768 & 0.539 & 0.654 \\
\hline & $\operatorname{LSD}_{\text {at } 5 \%}$ & 0.004 & 0.004 & 0.003 \\
\hline \multicolumn{5}{|c|}{ Interaction } \\
\hline \multirow{3}{*}{ 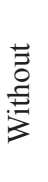 } & 0 & 0.718 & 0.498 & 0.608 \\
\hline & $\operatorname{Micro}(\mathrm{Fe}+\mathrm{Zn}+\mathrm{Mn})$ & 0.762 & 0.534 & 0.648 \\
\hline & Humic acid (humate K) & 0.751 & 0.524 & 0.638 \\
\hline \multirow{3}{*}{$\sum_{\substack{\Delta\\
}}$} & 0 & 0.730 & 0.508 & 0.619 \\
\hline & $\operatorname{Micro}(\mathrm{Fe}+\mathrm{Zn}+\mathrm{Mn})$ & 0.794 & 0.561 & 0.677 \\
\hline & Humic acid (humate K) & 0.769 & 0.541 & 0.655 \\
\hline \multirow{4}{*}{ 全 } & 0 & 0.742 & 0.516 & 0.629 \\
\hline & $\operatorname{Micro}(\mathrm{Fe}+\mathrm{Zn}+\mathrm{Mn})$ & 0.806 & 0.569 & 0.688 \\
\hline & Humic acid (humate $\mathrm{K}$ ) & 0.784 & 0.553 & 0.669 \\
\hline & $\operatorname{LSD}_{\text {at } 5 \%}$ & 0.007 & 0.007 & 0.005 \\
\hline
\end{tabular}

Chl. a= Chlorophyll a, Chl. b= Chlorophyll b, T Chl. total chlorophyll

Egypt. J. Soil. Sci. 59, No. 1 (2019) 
On the other hand; foliar application (control, mix of (Fe, $\mathrm{Zn}, \mathrm{Mn})$ and $\mathrm{HK}$ ) gave significant positive effect for average values of chlorophyll content during both seasons. The highest value noticed with mix of micro element $(0.787,0.555$ and 0.671 respectively comparing with the control treatment). This may be due to the participation of $\mathrm{Fe}$ in the formation of chlorophyll and $\mathrm{Zn}$ enzymatic role in starch formation and in protein synthesis; thus, a leading support to the claim made by El-Tohamy \& El-Greadly (2007), Kobraee et al. (2011) and Salih (2013).

The combined effects of organic fertilization and foliar application were significantly affected on chlorophyll content of leaves. It can be observed that the most suitable treatment, which achieved the highest mean values of traits, was connected with the plants treated with CRS + micro elements, while the lowest one was associated with the treatment of untreated plants.

\section{Macro and micro elements content}

Data in Table 5 indicate the effect of organic fertilization (control, FYM and CRS) and foliar application (control, mix of (Fe, $\mathrm{Zn}$, and $\mathrm{Mn}$ )and $\mathrm{HK}$ ) as well as their interactions on the average values of $\mathrm{N}, \mathrm{P}, \mathrm{K} \%, \mathrm{Fe}, \mathrm{Zn}$ and $\mathrm{Mn}\left(\mu \mathrm{g} \mathrm{g}^{-1}\right)$ content during both seasons of the experiment. Regarding to the effect of organic fertilization (without, FYM and CRS), data illustrated in Table 5 reveled that addition of organic fertilization in both forms increased average nutrition values of $\mathrm{N}, \mathrm{P}, \mathrm{K} \%, \mathrm{Fe}$, $\mathrm{Zn}$ and $\mathrm{Mn}\left(\mu \mathrm{g} \mathrm{g}^{-1}\right)$ during both seasons compared with the untreated plants. The highest average values of all elements recorded with using compost rice straw. Data indicated that $\mathrm{N}, \mathrm{P}, \mathrm{K} \%, \mathrm{Fe}, \mathrm{Zn}$ and $\mathrm{Mn}\left(\mu \mathrm{g} \mathrm{g}^{-1}\right)$ in leaves content was increased by CRS application due to increase in vegetative growth parameters with CRS. Similar results were obtained by El-Sharawy et al., (2003) who found that the concentration of N, P, K, Fe, Mn, Zn and $\mathrm{Cu}$ either in leaves or in grains of faba bean was significantly increased due to the application of rice straw composts. This increase in nutrients availability resulted in higher dry matter and grain yields of faba bean than untreated plants. Also, the same data indicated by El -Gizawy et al. (2013), Mahmoud et al. (2013) and Shafeek et al. (2017).

Data in Table 5 clearly show that foliar application with (control, and mix of $\mathrm{Fe}+\mathrm{Zn}+\mathrm{Mn}$ and $\mathrm{HK}$ ) significantly affected in nutrients by leaves of cowpea plants. The highest average mean values of $\mathrm{N}, \mathrm{P}, \mathrm{K} \%, \mathrm{Fe}, \mathrm{Zn}$ and $\mathrm{Mn}\left(\mu \mathrm{g} \mathrm{g}^{-1}\right)$ in cowpea plants were recorded by spraying plant with mix of (Fe, $\mathrm{Zn}$ and $\mathrm{Mn})$. This result may be due to sharing of foliar micronutrients such as iron, zinc and manganese, which iron in the formation of chlorophyll (Kolota and Osinska, 1999). Zn has essential element and plays a role in plant enzymes, which contain in a functional structural or many enzymes or regulatory co-factor and for photosynthesis, protein synthesis, the synthesis of auxin, sexual fertilization and cell division. Also, zinc plays a special role in synthesizing proteins, DNA and RNA. It has been discovered that iron is activator of a lot of enzymes and it assume vital part in plant growth and production, including chlorophyll synthesis, chloroplast development and protein synthesis Pingoliya et al. (2014) and El-Azab (2016).

The result in the same table, illustrated that the interaction effect between treatments under investigation, significantly affect the average values of N, P, K, Fe $\mathrm{Zn}$ and Mn concentration by adding different forms of micronutrients regardless of applied organic fertilization. The highest values of N, P, K, Fe, Zn and Mn contents were generally attained in plant treated with foliar application of the mix micronutrient treatment $(\mathrm{Fe}+\mathrm{Zn}+\mathrm{Mn})$ grown under compost rice straw as organic manure.

\section{Quality parameters}

Data presented in Table 6 show the effect of treating cowpea plants with organic fertilization, foliar application of the mix $(\mathrm{Fe}+\mathrm{Zn}+\mathrm{Mn})$ and their interactions on moisture, C. protein, $\mathrm{T}$. carbohydrates, C. fiber, ash and total sugar of cowpea seeds. It is clear from the presented data that treating cowpea plants with organic fertilization (control, FYM and CRS) as soil addition significantly affected moisture, C. protein, T. carbohydrates, C. fiber, ash and total sugar of cowpea seeds. Parameters increased with adding organic fertilizations, which recorded the highest values with using CRS, followed by FYM except with moisture \%, which decreased with using organic fertilization in both forms. The increase in protein as recorded previously due to the increase in nitrogen contents of leaves, which are speedily converted to protein and during grain development leaf $\mathrm{N}$ is transferred to grain for protein production. Also, improvement of these parameters may be due to the slow and continuous supply of both micro and macro nutrients, which might have helped in the assimilation of carbohydrates. These results are consistent with the finding of Nagavani and Subbian (2014). The acquired results are in pretty endorsement with El -Gizawy et al. (2013), Mahmoud et al. (2013) and Shafeek et al. (2017).

Results in Table 6 illustrated that the effect of foliar spray with (mix of different microelements, i.e. $\mathrm{Mn}, \mathrm{Zn}$ and $\mathrm{Fe}$ and potassium humate in comparison with untreated plants) on moisture, 
C. protein, T. carbohydrates, C. fiber, ash and total sugar of cowpea seeds. It is clear from the data that spraying cowpea plants with all tested nutrient enhanced significantly all studied traits. Parameters were increased with foliar application of mixed micronutrient treatment $(\mathrm{Mn}+\mathrm{Zn}+\mathrm{Fe})$. The increase in protein content due to zinc addition might be attributed to its involvement in nitrogen metabolism of plants. Chavan et al. (2012) stated that great values of maximum protein content in cowpea grains reported as a result of application $40 \mathrm{~kg} \mathrm{ha}^{-1}$ zinc over 0 and $20 \mathrm{~kg}$ zinc. Crops with applied zinc were more powerful than others and had a huge growth because zinc had a vital part in stabilizing DNA and RNA structure, and involves in biosynthesis of growth promoting hormones such as gibberellins and IAA (Mousavi, 2011). Kumar et al. (2002) reported an increase nodulation, protein content, nutrients uptake and protein yield with application of zinc at $9.0 \mathrm{~kg}$ $\mathrm{ha}^{-1}$ over control in cowpea. Safak et al. (2009) stated that zinc is an activator of many enzymes involved in photosynthesis, cell division and elongation. Thus crud fiber, crude protein and zinc concentration were significantly affected by zinc fertilization. Yadav et al. (2002) and Pingoliya et al. (2014) reported that with the application of $30 \mathrm{~kg}$ $\mathrm{P}_{2} \mathrm{O}_{5} \mathrm{ha}^{-1}$ and $4 \mathrm{~kg} \mathrm{Fe} \mathrm{ha}{ }^{-1}$, the protein content in seeds increased significantly comparing with their lower levels in mung bean. Manganese plays an important role of many enzyme systems. It affects the evolution of $\mathrm{O}_{2}$ in photosynthesis (Hill reaction). It has also, function in chloroplast as a part of electron-transfer (oxidation-reduction) reactions and electron transport system (Srivastava and Gupta, 1996)

TABLE 5. Average values of leaves macro and microelements content as affected with organic fertilization, foliar application as well as their interaction during two growing seasons of 2016 and 2017

\begin{tabular}{|c|c|c|c|c|c|c|c|}
\hline \multicolumn{2}{|r|}{ Treatments } & N\% & P\% & K\% & $\mathrm{Fe} \mu \mathrm{g} \mathrm{g}^{-1}$ & $\mathrm{Zn} \mu \mathrm{g} \mathrm{g}^{-1}$ & $\operatorname{Mn} \mu g g^{-1}$ \\
\hline \multicolumn{8}{|c|}{ Organic fertilization } \\
\hline \multicolumn{2}{|r|}{ Without } & 3.61 & 0.218 & 2.17 & 22.86 & 17.46 & 12.76 \\
\hline \multicolumn{2}{|r|}{ FYM } & 3.74 & 0.239 & 2.37 & 24.49 & 18.80 & 13.91 \\
\hline \multicolumn{2}{|r|}{ CRS } & 3.88 & 0.249 & 2.47 & 26.11 & 19.87 & 15.10 \\
\hline \multicolumn{2}{|r|}{$\mathrm{LSD}_{\text {at } 5 \%}$} & 0.06 & 0.003 & 0.03 & 0.04 & 0.08 & 0.01 \\
\hline \multicolumn{8}{|c|}{ Foliar application } \\
\hline \multicolumn{2}{|r|}{0} & 3.49 & 0.204 & 2.02 & 20.27 & 15.08 & 10.68 \\
\hline \multicolumn{2}{|r|}{$\operatorname{Micro}(\mathrm{Fe}+\mathrm{Zn}+\mathrm{Mn})$} & 3.91 & 0.259 & 2.58 & 29.66 & 22.74 & 17.81 \\
\hline & Humic acid (humate K) & 3.83 & 0.243 & 2.41 & 23.52 & 18.32 & 13.28 \\
\hline \multirow{2}{*}{\multicolumn{2}{|c|}{$\mathrm{LSD}_{\text {at } 5 \%}$}} & 0.03 & 0.005 & 0.03 & 0.04 & 0.03 & 0.03 \\
\hline & & \multicolumn{3}{|c|}{ Interaction } & & & \\
\hline \multirow{4}{*}{ 泀 } & 0 & 3.41 & 0.193 & 1.92 & 19.39 & 14.05 & 9.94 \\
\hline & $\operatorname{Micro}(\mathrm{Fe}+\mathrm{Zn}+\mathrm{Mn})$ & 3.75 & 0.235 & 2.35 & 26.81 & 21.14 & 15.96 \\
\hline & Humic acid (humate K) & 3.67 & 0.226 & 2.24 & 22.37 & 17.20 & 12.39 \\
\hline & 0 & 3.49 & 0.204 & 2.03 & 20.25 & 15.10 & 10.63 \\
\hline \multirow{3}{*}{ 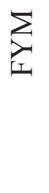 } & $\operatorname{Micro}(\mathrm{Fe}+\mathrm{Zn}+\mathrm{Mn})$ & 3.91 & 0.265 & 2.65 & 29.67 & 22.96 & 17.82 \\
\hline & Humic acid (humate K) & 3.83 & 0.247 & 2.44 & 23.54 & 18.35 & 13.28 \\
\hline & 0 & 3.58 & 0.215 & 2.12 & 21.18 & 16.09 & 11.47 \\
\hline \multirow[t]{3}{*}{$\stackrel{\widetilde{v}}{\widetilde{u}}$} & $\operatorname{Micro}(\mathrm{Fe}+\mathrm{Zn}+\mathrm{Mn})$ & 4.07 & 0.277 & 2.74 & 32.51 & 24.12 & 19.66 \\
\hline & Humic acid (humate K) & 3.98 & 0.256 & 2.56 & 24.65 & 19.41 & 14.17 \\
\hline & $\operatorname{LSD}_{\text {at } 5 \%}$ & 0.06 & 0.008 & 0.06 & 0.07 & 0.04 & 0.06 \\
\hline
\end{tabular}

Egypt. J. Soil. Sci. 59, No. 1 (2019) 
TABLE 6. Average values of seeds quality parameters as affected with organic fertilization, foliar application as well as their interaction during two growing seasons of 2016 and 2017

\begin{tabular}{|c|c|c|c|c|c|c|c|}
\hline & Treatments & $\begin{array}{c}\text { Moisture } \\
\%\end{array}$ & Protein \% & $\begin{array}{c}\text { Total } \\
\text { Carbohydrates } \\
\%\end{array}$ & $\begin{array}{c}\text { C. fiber } \\
\%\end{array}$ & $\begin{array}{c}\text { Ash } \\
\%\end{array}$ & T. sugar\% \\
\hline \multicolumn{8}{|c|}{ Organic fertilization } \\
\hline & Without & 11.78 & 21.63 & 60.43 & 6.13 & 4.95 & 7.28 \\
\hline & FYM & 10.97 & 22.40 & 61.28 & 6.46 & 5.18 & 7.54 \\
\hline & CRS & 10.08 & 23.06 & 62.07 & 6.91 & 5.50 & 7.80 \\
\hline \multirow{2}{*}{\multicolumn{2}{|c|}{$\operatorname{LSD}_{\text {at } 5 \%}$}} & 0.07 & 0.05 & 0.05 & 0.06 & 0.09 & 0.06 \\
\hline & & \multicolumn{3}{|c|}{ Foliar application } & & & \\
\hline & 0 & 12.48 & 21.04 & 59.78 & 5.85 & 4.76 & 7.08 \\
\hline & $\operatorname{Micro}(\mathrm{Fe}+\mathrm{Zn}+\mathrm{Mn})$ & 9.92 & 23.23 & 62.24 & 6.94 & 5.54 & 7.85 \\
\hline & Humic acid (humate K) & 10.43 & 22.81 & 61.76 & 6.70 & 5.32 & 7.69 \\
\hline \multirow{2}{*}{\multicolumn{2}{|c|}{$\mathrm{LSD}_{\text {at } 5 \%}$}} & 0.04 & 0.04 & 0.03 & 0.03 & 0.04 & 0.04 \\
\hline & & \multicolumn{3}{|c|}{ Interaction } & & & \\
\hline \multirow{4}{*}{ 咅 } & 0 & 13.09 & 20.66 & 59.32 & 5.65 & 4.63 & 6.92 \\
\hline & $\operatorname{Micro}(\mathrm{Fe}+\mathrm{Zn}+\mathrm{Mn})$ & 10.88 & 22.37 & 61.24 & 6.47 & 5.19 & 7.53 \\
\hline & Humic acid (humate K) & 11.37 & 21.85 & 60.73 & 6.26 & 5.02 & 7.38 \\
\hline & 0 & 12.51 & 21.04 & 59.81 & 5.84 & 4.80 & 7.08 \\
\hline \multirow{3}{*}{$\sum_{\text {空 }}$} & $\operatorname{Micro}(\mathrm{Fe}+\mathrm{Zn}+\mathrm{Mn})$ & 9.97 & 23.27 & 62.30 & 6.87 & 5.46 & 7.84 \\
\hline & Humic acid (humate K) & 10.43 & 22.88 & 61.72 & 6.66 & 5.27 & 7.69 \\
\hline & 0 & 11.84 & 21.43 & 60.22 & 6.05 & 4.86 & 7.23 \\
\hline \multirow{3}{*}{ 元 } & $\operatorname{Micro}(\mathrm{Fe}+\mathrm{Zn}+\mathrm{Mn})$ & 8.92 & 24.05 & 63.17 & 7.48 & 5.98 & 8.17 \\
\hline & Humic acid (humate K) & 9.48 & 23.71 & 62.82 & 7.19 & 5.67 & 7.99 \\
\hline & $\mathrm{LSD}_{\text {at } 5 \%}$ & 0.06 & 0.07 & 0.05 & 0.05 & 0.07 & 0.06 \\
\hline
\end{tabular}

Statistical analysis of the data in Table 6 revealed the average values of quality parameters as affected by the combination between the various treatments under investigation. It could be observed that; a positive effect was happened on the mean values of all quality parameters mentioned due to using the combination between the studied parameters. In this respect, the highest values; $(24.05,63.17,7.48$, 5.98 and $7.18 \%$ for C. protein, T. carbohydrates, C. fiber, ash and total sugar of cowpea seeds, respectively) were obtained for the treatment of CRS addition + mix of microelements, while the highest values of moisture was recorded for the untreated plants.

\section{Yield and its components}

No. of pods plant ${ }^{-1}$, No. of seed pod ${ }^{-1}, 100$ seed weight $(\mathrm{g})$ and seed yield $\left(\mathrm{Kg} \mathrm{fed}^{-1}\right)$ of cowpea plants were recorded in Table (7) as affected by addition of organic fertilization (FYM and CRS), foliar spray from (mix of micro elements and potassium humate) comparing with the untreated plants as well as its interaction. The yield and its component parameters were increased significantly in response to using organic fertilization. The increase in seed yield indicated with using CRS and recorded the highest mean values comparing with the untreated plants during both seasons. The relative increase in the seed yield with respect to control may be due to the beneficial effects of increasing organic matter in soil due to successive application of soil amendments. Organic matter decomposition leading to production of both organic of compounds and biochemical activities which together acted to stimulate plant growth and crop yields. As well as organic matter and Egypt. J. Soil. Sci. 59, No. 1 (2019) 
available elements originated from compost. In addition, with the application of compost, the yield was increased. Increases were attributed the improving action of compost on the soil physical properties as well as nutrients status in the soil, which enhance plant growth (El-Sanat, 2003). These results are similar to the findings of $\mathrm{El}-$ Gizawy et al. (2013), Mahmoud et al. (2013), Bandani et al. (2014) and Shafeek et al. (2017).

Regarding the effect of foliar application with (mix of micro elements and potassium humate) comparing with control on No. of pods plant ${ }^{-1}$, No. of seed pod ${ }^{-1}, 100$ seed weight $(\mathrm{g})$ and seed yield $\left(\mathrm{Kg} \mathrm{fed}^{-1}\right)$ of cowpea plants, at the same Table 7 , the mean values of the parameters for cowpea plant were significantly increased with the foliar application by some microelements, i.e. $\mathrm{Fe}, \mathrm{Zn}$ and Mn treatment. No. of pods plant ${ }^{-1}$, No. of seed pod ${ }^{-1}$, 100 seed weight $(\mathrm{g})$ and seed yield $\left(\mathrm{Kg} \mathrm{fed}^{-1}\right)$ of cowpea plants and the increment in yield parameters brought by the mix treatment of micronutrient $(\mathrm{Fe}+\mathrm{Zn}+\mathrm{Mn})$ comparing with the untreated plants. Mali et al., (2003) referred that, the increase in seed yield because of manganese, zinc and iron addition could possibly be due to the enhanced synthesis of protein and carbohydrates and their transport to the site of seed formation. These results are agreed with those of Nasri et al. (2011) and Balai et al., (2017). Also, Mevada et al., (2005) carried out a field experiment on urd bean to investigate the effect of the application of micronutrient ( $\mathrm{Zn}, \mathrm{B}$, Mo and $\mathrm{Fe}$ ) and said that under the application of chelated $\mathrm{Fe}$ obtained maximum grain yield over control.

The comparison among the means of the various combined treatments of organic fertilization, foliar application as shown in Fig. 2 reflected a significant effect on No. of pods plant ${ }^{-1}$, No. of seed pod ${ }^{-1}, 100$ seed weight $(\mathrm{g})$ and seed yield $\left(\mathrm{Kg} \mathrm{fed}^{-1}\right)$ of cowpea plants. The highest values were recorded with CRS + foliar application of microelements $(\mathrm{Fe}, \mathrm{Zn}$ and $\mathrm{Mn}$ ) during both seasons.

Availability of macro elements in soil after harvest

Concentration of available $\mathrm{N}, \mathrm{P}, \mathrm{K} \mu \mathrm{g} \mathrm{\textrm {g } ^ { - 1 }}$ found in the experimental soil after cropping with cowpea as affected with interaction of organic fertilizers as soil addition and foliar application of (mix of micro elements and potassium humate) are presented in Table 8. Owing to the nature and the pattern of mineralization, combined use of organic fertilizations improved the physico-chemical properties of the soil rather than application of only inorganic fertilizers. The buildup of available nitrogen, phosphorus and potassium in soil was significantly influenced by application of organic fertilizers. The results of present investigation revealed that increasing available nitrogen, phosphorus and potassium, and the highest mean values of them recorded with CRS followed by FYM. The contents of elements increased with adding of the studied organic fertilization, which already contained moderately amount of these elements. But the average values of nutrients in the soil tended to be over than that obtained. In this respect Kara et al., (2004) indicated that the application of organic fertilizations in the soil could be enriched soil if it is found feasible and applicable. Therefore, minerals will prefer to form chelates with organic compounds. By this way, extractable macro-nutrients concentrations will be minimized by using organic material. Similar results were recorded by Hellal et al. (2009).

TABLE 7. Average values of yield and its parameters as affected with individual organic fertilization, foliar application during two growing seasons of 2016 and 2017

\begin{tabular}{|c|c|c|c|c|}
\hline Treatments & $\begin{array}{c}\text { No } \\
\text { ofpodsplant }^{-1}\end{array}$ & $\begin{array}{c}\text { No } \\
\text { ofseedspod }^{-1}\end{array}$ & $\begin{array}{l}100 \text { seed } \\
\text { weight g }\end{array}$ & $\begin{array}{l}\text { seed yield } \\
\text { kgfed }^{-1}\end{array}$ \\
\hline \multicolumn{5}{|c|}{ Organic fertilization } \\
\hline Without & 20.00 & 6.89 & 16.90 & 935.78 \\
\hline FYM & 21.67 & 8.00 & 19.13 & 996.22 \\
\hline CRS & 22.22 & 8.67 & 20.08 & 1026.11 \\
\hline $\mathrm{LSD}_{\text {at } 5 \%}$ & 0.80 & 1.59 & 0.77 & 10.45 \\
\hline \multicolumn{5}{|c|}{ Foliar application } \\
\hline 0 & 18.33 & 6.11 & 15.46 & 897.44 \\
\hline $\operatorname{Micro}(\mathrm{Fe}+\mathrm{Zn}+\mathrm{Mn})$ & 23.44 & 9.33 & 21.32 & 1035.33 \\
\hline Humic acid (humate K) & 22.11 & 8.11 & 19.33 & 1025.33 \\
\hline $\mathrm{LSD}_{\text {at } 5 \%}$ & 0.79 & 0.75 & 0.73 & 12.18 \\
\hline
\end{tabular}

Egypt. J. Soil. Sci. 59, No. 1 (2019) 
TABLE 8. Average values of available N, P and K ( $\mu \mathrm{g} g-1)$ as affected with interaction adding of organic fertilization and foliar application during two growing seasons of 2016 and 2017

\begin{tabular}{|c|c|c|c|c|}
\hline & Treatments & Available $N-\mu g g^{-1}$ & Available $\mathrm{P}-\mu \mathrm{g} \mathrm{g}^{-1}$ & Available $\mathrm{K}$ - $\mu \mathrm{g} \mathrm{g}^{-1}$ \\
\hline \multirow{3}{*}{ 吾 } & 0 & 56.8 & 5.75 & 82.4 \\
\hline & $\operatorname{Micro}(\mathrm{Fe}+\mathrm{Zn}+\mathrm{Mn})$ & 59.2 & 6.23 & 90.6 \\
\hline & Humic acid (humate K) & 63.5 & 7.08 & 97.4 \\
\hline \multirow{3}{*}{ 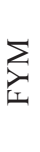 } & 0 & 70.3 & 9.13 & 125.3 \\
\hline & $\operatorname{Micro}(\mathrm{Fe}+\mathrm{Zn}+\mathrm{Mn})$ & 77.4 & 12.31 & 145.3 \\
\hline & Humic acid (humate K) & 88.9 & 14.21 & 152.9 \\
\hline \multirow{4}{*}{ 先 } & 0 & 73.7 & 10.62 & 136.4 \\
\hline & $\operatorname{Micro}(\mathrm{Fe}+\mathrm{Zn}+\mathrm{Mn})$ & 96.6 & 18.50 & 187.7 \\
\hline & Humic acid (humate K) & 92.1 & 16.41 & 168.5 \\
\hline & $\operatorname{LSD}_{\text {at } 5 \%}$ & 0.92 & 0.21 & 0.78 \\
\hline
\end{tabular}

\section{Conclusion}

The obtained results showed that foliar spraying of cowpea plants with microelements (Fe, $\mathrm{Zn}$ and $\mathrm{Mn}$ ) is very beneficial to the crop growth and yield. Hence, it could be suggested that cowpea plants grown under the experiment and similar growing conditions and foliar sprayed with $(\mathrm{Fe}+\mathrm{Zn}+\mathrm{Mn})$ under compost rice straw as form of organic fertilization to produce high quantity and good quality of pods and dry seed yields suitable for marketing.

\section{References}

Amanullah, M. M., Somasundaram, E., Vaiyapuri, K. and Sathyamoorthi, K. (2007) Poultry manure to crops -A Review. Agric. Rev., 28, 216 -222.

AOAC (2000) Association of Official Analytical Chemists, $17^{\text {th }}$ ed. of A.O.A.C. international published by A.O.A.C. international Maryland, U.S.A., 1250 pp.

Balai, K., Sharma, Y., Jajoria, M., Deewan, P. and Verma, R. (2017) Effect of Phosphorus, and Zinc on Growth, Yield and Economics of Chickpea (Cicer aritinum L.). Int. J. Curr. Microbiol. App. Sci., $6(3), 1174-1181$.

Bandani, M., Mobasser, H. R. and Sirusmehr, A. (2014) Effect of organic fertilizer on quantitative yield of mung beam (Vigna radiata L). J. Nov. Appl Sci., 3 (4), 367-370.

Chavan, A. S.; Khafi,M. R., Raj, A. D. and Parmar, R. M. (2012) Effect of potassium and zinc on yield, protein content and uptake of micronutrients on cowpea (Vigna unguiculata (L.) walp). Agric. Sci., Digest, 32, 175-177.
Dugie, I. Y., Omoisui, L. O., Eketeneme, F. and Kamara, A.Y. (2009) "Farmers Guide to Cowpea Production in West Africa", 46-48.

Eisa, G. S. A. and Ali, T. B. (2014) Impact spraying of some microelements on growth, yield, nitrogenase activity and anatomical features of cowpea plants. World J. Agric. Sci., 10 (2, 57-67.

El -Gizawy, E. S. A.; Atwa,A. A. I. , Talha, N. I. and Mostafa, R. A. I. (2013) Effect of compost and compost tea application on faba bean crop and some soil biological and chemical properties. $J$. Soil Sci. and Agric. Eng., Mansoura Univ., 4 (9), 863-874.

El-Azab, M. E. (2016) Effects of Foliar NPK Spraying with Micronutrients on Yield and Quality of Cowpea Plants. Asian J. Applied Sci., 4 (2), 526-533.

El-Sanat, G. M. A. (2003) Effect of amelioration processes on nutrients status in salt affected soils. M.Sc .Thesis, Fac. Agric., Menufiya Univ., Egypt.

El-Sharawy, M. A. O., Aziz, M. A. and Ali,L. K. M. (2003) Effect of the application of plant residues composts on some soil properties and yield of wheat and maize plants. Egypt. J. Soil Sci. 43 (3), 421- 434.

El-Tohamy, W. A. and El-Greadly, N. H. M. (2007) Physiological Responses, Growth, Yield and Quality of Snap Beans in Response to Foliar Application of Yeast, Vitamin E and Zinc under Sandy Soil Conditions. Australian J. Basic and Applied Sci., 1 (3), 294-299.

FAO. (1980) Physical and Chemical Methods of Soil and Water Analysis. Soils Bull. No. 10, FAO,

Egypt. J. Soil. Sci. 59, No. 1 (2019) 
Rome, Italy.

FAO. Food energy - methods of analysis and conversion factors (2003) FAO food and nutrition paper 77. Report of a Technical Workshop, Rome, 3-6 December 2002.

FAO (2006) FAOSTAT Agricultural Data. Agricultural production, crops, primary. United Nations Food and Agriculture Organization.

FAO Rice Market Monitor (2013) Trade and Markets Division Food and Agriculture Organization of the United Nations, vol. 16 (1), pp. 2-37.<http:// www.fao.org/economic/est/publications/ricepublications/rice-market-monitor-rmm/en/ January2013>.

Fawole, O. B., Ajayi, T. J., Aduloju, M. O. and Olaniyan, J. O. (2010) The use of Parkia husk and melon wastes as soil amendment. Journal of Agric. Research and Development, University of Ilorin (In Press).

Gavrilenko V. F. and Zigalova, T. V. (2003) The Laboratory Manual for the Photosynthesis. Academia, Moscow. 256 стр. (in Russian).

Ghosh, Ch. (2004) Integrated vermi-pisciculture - an alternative option for recycling of solid municipal waste in rural India. Bioresour. Technol. 93 (1), $71-75$.

Gomez, K. A. and Gomez, A. A. (1984) "Statistical Procedures for Agricultural Research". John Wiley and Sons, Inc., New York.pp:680.

Hanajima, D., Kuroda, K., Fukumoto, Y., Haga, K. (2006) Effect of addition of organic waste on reduction of Escherichia coli during cattle feces composting under high-moisture condition. Bioresour. Technol. 97, 1626-1630.

Hellal, F. A. (2007) Composting of rice straw and its influences on iron availability in calcareous soil. Res. J. Agric. and Biol. Sci., 3 (2), 105-114.

Hellal, F. A., Abd El-Hady, M. and Ragab, A. A. M. (2009) Effect of organic amendments on nutrient availability and uptake by faba bean plants fertilized by rock phosphate and feldspar. American J. Agric. \& Enveron. Sci., 6 (3), 271-279.

Kara, E., Pirlak, U. and Özdilek, H. G. (2004) Evaluation of heavy metals' $(\mathrm{Cd}, \mathrm{Cu}, \mathrm{Ni}, \mathrm{Pb}$, and $\mathrm{Zn}$ ) distribution in sowing regions of potato fields in the province of nigde, turkey. Water, Air, and Soil Pollution, 153, 173-186.

Klute, A. (1986) Methods of Soil Analysis. Part-1:
Physical and Mineralogical Methods ( $\left.2^{\text {nd }}\right)$ American Society of Agronomy, Madison, Wisconsin. U.S.A.

Kobraee, S., N. Noor Mohamadi, H. Heidari Sharifabad, F. Darvish Kajori and B. Delkhosh (2011) Influence of micronutrient fertilizer on soybean nutrient composition. Indian J. Sci. Technol., 4 (7). Available online at: http://www.indjst.org/archive/ vol.4.issue.7/july11kobraee-9.pdf.

Kolota, E. and Osinska, M. (1999) Efficiency of foliar nutrition of field vegetables grown at different nitrogen rates. Hasłoogro. 66, 60 - 62 .

Kumar, P., Nagaraju, C. and Yogananda, P. (2002) Studies on sources of phosphorus and zinc levels oncowpea in relation to nodulation, quality and nutrient uptake. Crop Res., 24, 299-302.

Lincoln, T. and Zeiger, E. (2002) Plant Physiology, Publisher, Sinauer Associates; 3 edition. Pb.690.

Mahmoud, R. A., EL- Desuki, M., Abdel-Mouty, M. M. and Ali, A.H. (2013) Effect of compost levels and yeast extract application on the pea plant growth, pod yield and quality. Journal of Applied Sciences Research, 9 (1), 149 -155.

Mali, G. C., Sharma, N. N.,Acharya, H. K. , Gupta,S. K. and Gupta, P. K. (2003) Response of pigeon pea to $\mathrm{S}$ and $\mathrm{Zn}$ fertilization on Vertisols in south-eastern plain of Rajasthan. Advances in Arid Legumes Research, pp. 267-271. Indian Arid Legumes Society, Scientific Publishers (India), Jodhpur.

Marschner, H. (1998) Mineral Nutrition of Higher Plants. $2^{\text {nd }}$. Academic Press, Harcourt Brace and Company, Publisher London, San Diego, New York Boston, Sydney, Tokyo, Toronto, pp. 864.

Mevada, K. D., Patel,J. J. and Patel,K. P. (2005) Effect of micronutrients on yield of urdbean. Indian $J$. Pluse Res., 18, 214-216.

Misra, R.V., Roy, R.N. and Hiraoka, H. (2003) Onfarm Composting Methods. Food and Agriculture Organization of the United Nations (FAO), Rome, pp. 1-35.

Mousavi, S. R. (2011) Zinc in crop production and interaction with phosphorus. Australian J. Basic and Applied Sci., 5, 1503-1509.

Nagavani, A. V. and Subbian, P. (2014) Effect of poultry manure on quality of hybrid maize grain. Current Biotica., 7 (4), 332-335.

Nardi, S., Pizzeghello, D., Renero,F. and Muscobo , A. (1999) Biological activity of humic substances

Egypt. J. Soil. Sci. 59, No. 1 (2019) 
extracted from soil under different vegetation cover. Commun. Soil Sci. Plant Anal., 30, 621-634.

Nasri, M., Khalatbari, M. and Farahani, H. A. (2011) Zn-foliar Application Influence on Quality and Quantity Features in Phaseolous Vulgaris under Different Levels of $\mathrm{N}$ and $\mathrm{K}$ Fertilizers. $A d v$. Environ. Biol., (Adv. Environ. Biol.) 5 (5), 839846. Available online at: http://www.aensionline. com/aeb/2011/839-846.pdf

Ozores-Hampton, M. P., Stansly, P. A. and Salame, T. P. (2011) Soil chemical, biological and physical properties of a sandy soil subjected to long-term organic amendments. J. Sustain. Agric., 353, 243259.

Page, A.L., Miller, R.H. and Keeney, D.R. (1982) Methods of Soil Analysis. Part-2: Chemical and Microbiological Properties. (2 nd $^{\text {ed.) }}$ American Society of Agronomy, Madison, Wisconsin. USA.

Pennington, J. A.; van Devender, K. and Jennings, J. A. (2015) Nutrient and fertilizer value of dairy manure. Agric. Nat. Res., 1-5.

Pingoliya, K. K., Dotaniya, M. L. and Lata, M. (2014) Effect of iron on yield, quality and nutrient uptake of chickpea (Cicer arietinum L.). African J. Agric. Res., 9 (37), 2841-2845.

Safak, C.; Hikmet, S., Bulent, B., Oseyin, A. and Bither, C. (2009) Effect of zinc on yield and some related trades of Alfa-alfa. J. Turkish Agric., 14,136 143.

Salih, H. M. (2013) Effect of Foliar Fertilization of Fe, $\mathrm{B}$ and $\mathrm{Zn}$ on nutrient concentration and seed protein of Cowpea "Vigna Unguiculata". IOSR J. Agric. and Veterinary Sci., 6 (3), 42-46. www.iosrjournals. org

Senjobi, B. A., Peluola, C. O., Senjobi, C. T., Lawal, I. O. and Salami, B. T. (2010) Performance of Cochorus olitorius as influenced by soil type and organic manure amendments in Yewa North Local Government Area, Ogun State. African Journal of Biotechnology, 9 (33), 5309-5312.

Shafeek, M. R., Shaheen, A. M., Hafez, M. M., Mahmoud, A. R. and Ali, A. H. (2017) Influence of cattle manure levels on the snap bean cultivars grown in sandy soil condition. Middle East J. Appl. Sci., 7(3), 4 30- 438.

Shumaila, G. and Safdar, M. (2009) Proximate Composition and Mineral Analysis of Cinnamon. Pakistan J. of Nutrition; 8 (9), 1456-1460. http:// dx.doi.org/10.3923/pjn.2009.1456.1460

Srivastava, P. C. and Gupta, U.C. (1996) Trace Elements in Crop Production. Science Pub. Inc. Lebanon, NH03766 USA, pp: 366.

Westerman, R.L. (Ed.). (1990) Soil Testing and Plant Analysis: Third edition. Number 3 in the Soil Science Society of America Book Series. pp. 275-298. Soil Science Society of America, Inc., Madison, Wisconsin, USA.

Yadav, P. S., Kameriya, P. R. and Rathore, S. (2002) Effect of phosphorus and iron fertilization on yield, protein content and nutrient uptake in mung bean on loamy sand soil. J. Indian Soc. Soil Sci., 50, 225 226.

(Received:13/ $1 / 2019$ accepted:24/ 3 /2019) 


\section{تعظيم الاستفاده من بعض الاسمده العضويه لإنتاج أعلى محصول من اللوبيا

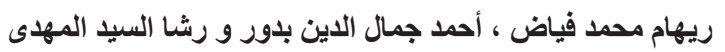

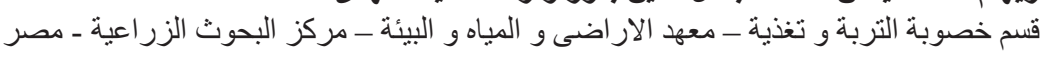

نفذت تجربتان حقليتان في الأر اضي الطينية بمنطقة وسط الدلتا فى محطه البحوث الزر اعيه بمنطقه تاج العز

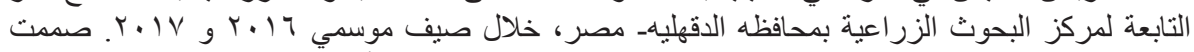

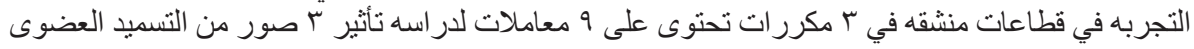

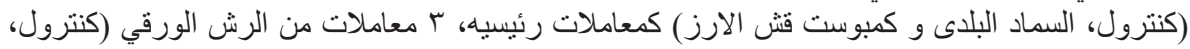

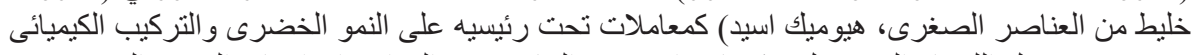

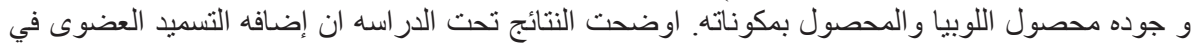

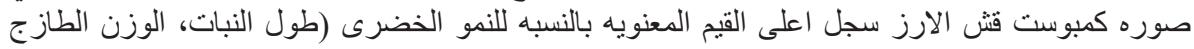

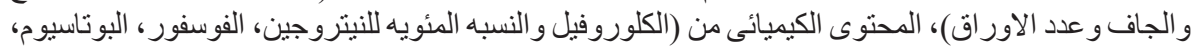

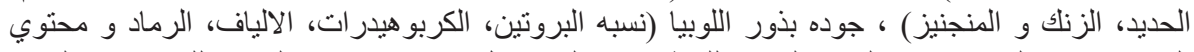

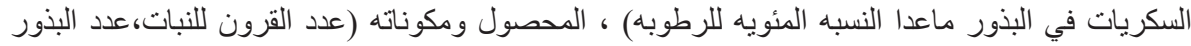

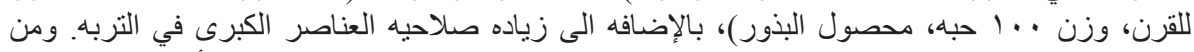

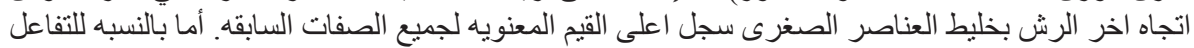

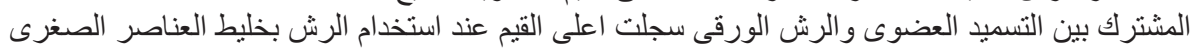
تحت التسميد العضوى من كمبوست فش التش الأرز 